\title{
ENVIRONMENTAL PERFORMANCE IMPROVEMENT FOR SMALL AND MEDIUM-SIZED SLAUGHTERHOUSES IN VIETNAM
}

\author{
Pham Hong Nhat \\ Vietnam Institute for Tropical Technology and Environmental Protection (VITTEP), Vietnam. \\ $\mathrm{PhD}$ student at the Environmental Policy Group of Wageningen University, the Netherlands.
}

\begin{abstract}
The economic reform in Vietnam, known as "Doi Moi", triggered in 1986 has brought about unprecedented growth not only in the industrial sector, but also in the field of agriculture with both cultivation and breeding activities. With the number of 6.71 million of cattle and 21.74 million of pigs (data 2001), slaughtering activities appear to be good business in the country. In solely Hochiminh City, the largest economic center, there are 42 slaughter units of which 41 are medium-, small- and micro-sized. VISSAN, the only large-sized abattoir of the country, is also located in this city. Though for a long time slaughtering has been regarded as a low technology operation and thus, not the sort of subject that would be taken seriously by research scientists, recently however, the increase of public awareness on environmental problems caused by slaughtering activities attracts more attention of not only administrative authorities but environmental research scientists as well. This study provides an analysis of the negative environmental impacts caused by small- and medium-sized slaughterhouses in the Hochiminh City region, and describes the shortcomings and causes of the present poor environmental performance and management of this agro-industry sub-sector. The study emphases that main environmental problems caused by the small- and medium-sized slaughterhouses are the uncontrolled use of ground water and the discharge of untreated wastewater that has high contents of organics released from the animal feces and blood, parasite eggs and pathogenic bacteria that might easily contaminate the receiving environment and endanger human health. The study concludes that the application of pollution prevention concept is crucial to improve environmental performance of small- and medium-sized slaughterhouses in Vietnam.
\end{abstract}

\section{Introduction}

Until recently animal slaughtering in Vietnam has been regarded in general as a low technology operation. As a result, this agro-industry sub-sector has never been the sort of subject that would be taken seriously by research scientists. Recently however, the increase of public awareness on food safety related to and environmental problems caused by slaughtering activities attracts more and more attention of not only the competent administrative authorities but environmental scientists as well.

\subsection{Slaughter industry in Vietnam}

Doi Moi, Vietnamese for "economic renewal", triggered in Vietnam in 1986 and has brought about unprecedented growth of the national economic outputs. Thanks to Doi Moi, the former centrally planned economy has gradually been transformed into a multisectoral economy guided by market-economy (Wolff, 1999). As a result, fast growth rate has been reached not only in the industrial sector, but also in the both fields of agriculture including cultivation and breeding production activities.

Regarding the field of breeding production, national statistic figures (General Statistics Office, 2002) in Table 1 show the number of cattle, pigs and poultry in the whole country in the 
period of the last ten years. It is clear that there except for slight decreases in the number of buffaloes and beeves in the year 2000 and 2001, the growth of other figures seems to have been rather steady.

Table 1. Livestock population in Vietnam

\begin{tabular}{|c|c|c|c|c|c|}
\hline & $\begin{array}{c}\text { Buffaloes } \\
\text { (x 1,000) }\end{array}$ & $\begin{array}{c}\text { Beeves } \\
(\mathrm{x} 1,000)\end{array}$ & $\begin{array}{c}\text { Pigs } \\
(\mathrm{x} 1,000)\end{array}$ & $\begin{array}{c}\text { Goats \& sheep } \\
(x 1,000)\end{array}$ & $\begin{array}{c}\text { Poultry } \\
(\mathrm{x} 1,000,000)\end{array}$ \\
\hline 1990 & 2854.1 & 3116.9 & 12260.5 & 372.3 & 107.4 \\
\hline 1991 & 2858.6 & 3135.6 & 12194.3 & 312.5 & 109.0 \\
\hline 1992 & 2886.5 & 3201.8 & 13891.7 & 312.3 & 124.5 \\
\hline 1993 & 2960.8 & 3333.0 & 14873.9 & 353.0 & 133.4 \\
\hline 1994 & 2977.3 & 3466.8 & 15587.7 & 427.9 & 137.8 \\
\hline 1995 & 2962.8 & 3638.9 & 16306.4 & 550.5 & 142.1 \\
\hline 1996 & 2953.9 & 3800.0 & 16921.7 & 512.8 & 151.4 \\
\hline 1997 & 2943.6 & 3904.8 & 17635.9 & 515.0 & 160.6 \\
\hline 1998 & 2951.4 & 3987.3 & 18132.4 & 514.3 & 166.4 \\
\hline 1999 & 2955.7 & 4063.6 & 18885.8 & 470.8 & 179.3 \\
\hline 2000 & 2897.2 & 4127.9 & 20193.8 & 543.9 & 196.1 \\
\hline 2001 & 2819.4 & 3896.0 & 21740.7 & 560.6 & 215.8 \\
\hline
\end{tabular}

Source: General Statistics Office, 2002.

These figures also suggest that there can be a good resource for the slaughtering activities in the country. In fact, according to the Department of Veterinary of Vietnam (2003) in the whole country there are some 12,000 slaughter units with very different capacities, which vary from 1 to more than 1,000 head per night pig kill.

All enterprises in Vietnam are classified by sizes using Vietnamese definition, which was elaborated by the Government of Vietnam (in its Document 681-CP/KTN issued on June 20, 1998) and which considers Small and Medium sized Enterprises (SMEs) as the ones that have a maximum registered capital of VND 5 billion (equivalent to about EUR 375,000) and/or employ less than 200 employees. According to this definition, VISSAN is the only slaughter unit in the country that can be classified as large-sized. This abattoir is also the only modern slaughter unit in the country. It is located in Hochiminh City and consists of two cattle slaughter lines and three pig slaughter lines and also a meat product processing plant. All the remaining existing slaughter units in Vietnam can be classified as medium and small-sized.

In practice, except for VISSAN, all the existing slaughter units in Vietnam are classified by the city/provincial Sub-department of Veterinary, and are so called, "centralized slaughter houses" when having a capacity more than around 10 head per night pig kill and "slaughter points" when having a capacity less than around 5 head per night pig kill ${ }^{1}$. The "centralized slaughter houses" meet well with the criteria set for SMEs, while the "slaughter points" seem too small to be classified as SMEs, though their number is huge, and thus can be informally classified as micro-sized. The micro-sized slaughter points in fact operate on family business base and scattered mainly in thinly populated areas. Within the number of 12,000 slaughter units existing in the country there are only about 350 "centralized slaughter houses", which will be called as "slaughter houses" thereafter throughout this paper, while the remaining number is "slaughter points". Both the number and capacity of slaughter houses and slaughter points are distributed very unequally in the country. According to the Department of Veterinary of Vietnam (2003) slaughter houses are concentrated in the Southern provinces much more than in the Northern and Middle parts of the country. In contrast to that, slaughter points exist with a much higher number in the Northern provinces compared with the other parts of the country. Table 2 below summarizes some figures for further illustration of the situation. 
Table 1. Data on the number of slaughter houses and slaughter points existing in some provinces of Vietnam

\begin{tabular}{||r|r|r|l|r|r|l|r|r||}
\hline \multicolumn{4}{|c|}{ Northern part } & \multicolumn{3}{c|}{ Middle part } & \multicolumn{3}{c|}{ Southern part } \\
\hline \multicolumn{1}{|c|}{ Province } & \multicolumn{1}{|c|}{ SH } & \multicolumn{1}{c|}{ SP } & \multicolumn{1}{c|}{ Province } & \multicolumn{1}{c|}{ SH } & \multicolumn{1}{c|}{ SP } & \multicolumn{1}{c|}{ Province } & \multicolumn{1}{c|}{ SH } & SP \\
\hline Ha Noi & 4 & NA & Nghe An & 10 & NA & Dak Lak & 57 & NA \\
\hline Hai Phong & 8 & 410 & Ha Tinh & 1 & 1200 & Tien Giang & 53 & 0 \\
\hline Thai Binh & 2 & NA & Quang Tri & 4 & 100 & Binh Phuoc & 52 & 0 \\
\hline Nam Dinh & 0 & 1180 & Thuathien Hue & 6 & 151 & Binh Duong & 13 & 19 \\
\hline Hung Yen & 0 & 938 & Quang Ngai & NA & 542 & Tay Ninh & 54 & 52 \\
\hline Bac Ninh & 0 & 942 & Binh Thuan & 0 & 339 & Long An & 40 & 0 \\
\hline Quang Ninh & 3 & 822 & Ninh Thuan & 1 & 74 & Ben Tre & 23 & 0 \\
\hline Thai Nguyen & 0 & 641 & & & & Hochiminh City & 30 & 12 \\
\hline Vinh Phuc & 0 & 775 & & & & & & \\
\hline Ha Nam & 0 & 424 & & & & & & \\
\hline \hline
\end{tabular}

Source: Department of Veterinary of Vietnam (2003), and

Department of Veterinary of Vietnam, South Regional Office (2003).

Note: SH: Slaughter houses

SP: Slaughter points

NA: Data not available

\subsection{Slaughter industry in Hochiminh City}

As clearly seen in the Section 1.1 above, slaughter houses are concentrated in a much higher density in South Vietnam compared with the other parts of the country. A reason for this could be the fact that market economy was introduced to this part earlier. A good example for analysis could be brought from Hochiminh City, the socio-economic and business capital of the South Vietnam.

Although the number of animal slaughter houses in this city is not the highest one compared with other provinces of Vietnam, its slaughter capacity is undoubtfully the biggest in the country. While the average slaughter capacity of all slaughter houses in the country is far below 30 head per night animal kill, the figure for Hochiminh City is about 180 (calculated from report by Sub-department of Veterinary of Hochiminh City, 2002b). This is not only because of the higher meat consumption rate of the citizens at this 6 million people city, but also because of its high capacity in animal meat product processing.

According to the Sub-department of Veterinary of Hochiminh City (2002a and 2002b), there are scattered in the city 42 legally registered slaughter units, including 30 slaughter houses and 12 slaughter points. All existing slaughter units in Hochiminh City are summarized in Table 2. Within this number, only one (VISSAN) is large-sized, six are medium-sized, 23 are smallsized and the remaining 12 are micro-sized. Except for two slaughter houses, including VISSAN and the $\mathrm{Cu} \mathrm{Chi}$ Town, that have cattle slaughtering licenses and the Tan Quy that has a goat slaughtering license, all the remaining units have been licensed to slaughter pigs only.

Table 2. Situation of the existing slaughterhouses in Hochiminh City

\begin{tabular}{|c|c|c|c|c|c|c|c|c|c|c|c|}
\hline \multirow[t]{2}{*}{ No } & \multirow[t]{2}{*}{ Slaughter unit } & \multirow{2}{*}{$\begin{array}{c}\text { Design } \\
\text { capacity } \\
\text { Head/day }\end{array}$} & \multirow{2}{*}{$\begin{array}{c}\text { Actual } \\
\text { capacity } \\
\text { Head/day }\end{array}$} & \multicolumn{3}{|c|}{ Location } & \multicolumn{3}{|c|}{$\begin{array}{l}\text { Hygienic } \\
\text { condition }\end{array}$} & \multicolumn{2}{|c|}{$\begin{array}{l}\text { Working } \\
\text { condition }\end{array}$} \\
\hline & & & & L1 & L2 & L3 & H1 & H2 & H3 & W1 & W2 \\
\hline 01 & VISSAN & $\begin{array}{l}2400 \text { pig } \\
300 \text { cattle }\end{array}$ & $\begin{array}{l}400 \\
100\end{array}$ & & $\mathrm{x}$ & & $\mathrm{x}$ & & & $\mathrm{x}$ & $\mathrm{x}$ \\
\hline
\end{tabular}




\begin{tabular}{|c|c|c|c|c|c|c|c|c|c|c|c|}
\hline 02 & Nam Phong & 800 pig & 1200 & $\mathrm{x}$ & & & & $\mathrm{x}$ & & & $\mathrm{x}$ \\
\hline 03 & Tabico & 300 pig & $600-700$ & $\mathrm{x}$ & & & $\mathrm{x}$ & & & $\mathrm{x}$ & $\mathrm{x}$ \\
\hline 04 & District 12 central & 400 pig & 300 & & & $\mathrm{x}$ & $\mathrm{x}$ & & & & $\mathrm{x}$ \\
\hline 05 & Station 4 & 500 pig & $250-300$ & $\mathrm{x}$ & & & & $\mathrm{x}$ & & $\mathrm{x}$ & \\
\hline 06 & Binh Chanh central & 1000 pig & $900-1000$ & & & $\mathrm{x}$ & $\mathrm{x}$ & & & & $\mathrm{x}$ \\
\hline 07 & Hoc Mon Town & 300 pig & $280-300$ & & $\mathrm{x}$ & & $\mathrm{x}$ & & & & $\mathrm{x}$ \\
\hline 08 & Go Vap food store & 100 pig & $140-150$ & $\mathrm{x}$ & & & & $\mathrm{x}$ & & & $\mathrm{x}$ \\
\hline 09 & 213 Ben Binh Dong & 150 pig & $140-150$ & $\mathrm{x}$ & & & & $\mathrm{x}$ & & $\mathrm{x}$ & $\mathrm{x}$ \\
\hline 10 & Phong Phu & 50 pig & 100 & & $\mathrm{x}$ & & & $\mathrm{x}$ & & & $\mathrm{x}$ \\
\hline 11 & Ap 3 Binh Chanh & 30 pig & 10 & & & $\mathrm{x}$ & & $\mathrm{x}$ & & & \\
\hline 12 & Ba Diem & 500 pig & $150-160$ & & $\mathrm{x}$ & & & $\mathrm{x}$ & & & $\mathrm{x}$ \\
\hline 13 & Xuan Thoi Son & 30 pig & 40 & & $\mathrm{x}$ & & & $\mathrm{x}$ & & & $\mathrm{x}$ \\
\hline 14 & Dong Thanh & 20 pig & 25 & & $\mathrm{x}$ & & & $\mathrm{x}$ & & & \\
\hline 15 & Thu Duc Town & 50 pig & 50 & $\mathrm{x}$ & & & & $\mathrm{x}$ & & & $\mathrm{x}$ \\
\hline 16 & Hiep Binh Chanh & 50 pig & 55 & & $\mathrm{x}$ & & & $\mathrm{x}$ & & & $\mathrm{x}$ \\
\hline 17 & Tam Binh & 50 pig & 40 & & $\mathrm{x}$ & & & $\mathrm{x}$ & & & $\mathrm{x}$ \\
\hline 18 & Binh Trung Dong & 30 pig & 20 & & $\mathrm{x}$ & & & $\mathrm{x}$ & & & \\
\hline 19 & Thu Thiem & 30 pig & 10 & & $\mathrm{x}$ & & & $\mathrm{x}$ & & & \\
\hline 20 & Long Thanh My & 20 pig & 15 & & $\mathrm{x}$ & & & & $\mathrm{x}$ & & \\
\hline 21 & Phuoc Long & 30 pig & 12 & $\mathrm{x}$ & & & & $\mathrm{x}$ & & & $\mathrm{x}$ \\
\hline 22 & Cu Chi Town & $\begin{array}{c}50 \text { pig } \\
40 \text { cattle } \\
\end{array}$ & $\begin{array}{l}30 \\
40 \\
\end{array}$ & & & $\mathrm{x}$ & & $\bar{x}$ & & & \\
\hline 23 & Phu Hoa Dong & 30 pig & 25 & $\mathrm{x}$ & & & & $\mathrm{x}$ & & & \\
\hline 24 & Tan Thanh Dong & 30 pig & 20 & & $\mathrm{x}$ & & & $\mathrm{x}$ & & & \\
\hline 25 & Tan Phu Trung & 30 pig & 30 & & $\mathrm{x}$ & & & $\mathrm{x}$ & & & $\mathrm{x}$ \\
\hline 26 & Phuoc Thanh & 30 pig & 12 & & $\mathrm{x}$ & & & $\mathrm{x}$ & & & $\mathrm{x}$ \\
\hline 27 & Tan Thuan Dong & 40 pig & 20 & & & $\mathrm{x}$ & & $\mathrm{x}$ & & & $\mathrm{x}$ \\
\hline 28 & Tan Quy & 30 goat & 20 & & $\mathrm{x}$ & & $\mathrm{x}$ & & & & $\mathrm{x}$ \\
\hline 29 & Nha Be Town & 50 pig & $80-100$ & $\mathrm{x}$ & & & & & $\mathrm{x}$ & & \\
\hline 30 & Phuoc Kieng & $200 \mathrm{pig}$ & 55 & & $\mathrm{x}$ & & & $\mathrm{x}$ & & & $\mathrm{x}$ \\
\hline 31 & Trung Lap Ha & 10 pig & 3 & $\mathrm{x}$ & & & & $\mathrm{x}$ & & & $\mathrm{x}$ \\
\hline 32 & An Nhon Tay & 10 pig & 8 & & $\mathrm{x}$ & & & $\mathrm{x}$ & & & $\mathrm{x}$ \\
\hline 33 & An Phu & 10 pig & 6 & & $\mathrm{x}$ & & & $\mathrm{x}$ & & & $\mathrm{x}$ \\
\hline 37 & Can Thanh (4) & 2 pig/each & 9 & $\mathrm{x}$ & & & & & $\mathrm{x}$ & & $\mathrm{x}$ \\
\hline 40 & Binh Khanh (3) & 2 pig/each & 7 & $\mathrm{x}$ & & & & & $\mathrm{x}$ & & $\mathrm{x}$ \\
\hline \multirow[t]{2}{*}{42} & An Thoi Dong (2) & 2 pig/each & 5 & & & & & & $\mathrm{x}$ & & $\mathrm{x}$ \\
\hline & Total & & & 19 & 19 & 5 & 6 & 26 & 11 & 4 & 33 \\
\hline
\end{tabular}

Note: Large-sized Medium-sized $\square$ Small-sized Micro-sized

L1: Location is within a densely residential area L2: Location is within a thinly populated area L3: Location is isolated from residential areas

H1: Fair hygienic condition $\mathrm{H} 2$ : Acceptable hygienic condition H3: Poor hygienic condition

W1: Workers are provided with labor protection facilities

W2: Regular health examination is carried out for workers

Hochiminh City has been selected the place to carry out case studies for this research because of the following reasons:

- The concentration of the slaughter units in Hochiminh City is rather high;

- Operation capacities of the slaughter units in Hochiminh City range largely from one to another, from 2 head per night pig kill at some remote slaughter points up to 1200 head per night pig kill at the Nam Phong Slaughter House; and 
- Locations of the existing slaughter units in Hochiminh City can represent the characteristics of all other parts of the country including big cities, newly formed towns, peri-urban and rural areas.

\section{Operation of slaughter houses}

\subsection{Case study selection and the profiles}

Six slaughter units in Hochiminh City were selected for this study. They included three mediumsized and three small sized slaughter houses. The selected slaughter houses are located in five different districts. Locations of the studied sites are shown in Figure 1. Profiles of the selected cases are summarized below.

\section{Binh Chanh Central Slaughter House}

This slaughter house is located in Binh Chanh district which is one of the newly urbanized districts of Hochiminh City and is about $12 \mathrm{~km}$ west from the city centre. It is among the very few slaughter houses that are isolated from residential areas. Located on a large piece of land, the slaughter house has a large area for pigs to rest before being slaughtered. The slaughter house has a design capacity of 1000 head per night pig kill. Its actual capacity is $900-1000$ head per night pig kill depending on the available amount of pigs and on the seasonal market demand.

Binh Chanh Central Slaughter House is shared by seven owners, i.e. there are seven working groups working similarly with almost the same activities and at the same time every night from 23:00 till 4:00 of the next morning. Maximum number of workers was some 150. Each group possesses 2-3 scalding tanks, making the total number of scalding tanks at the site of 16 . Wood is used to fire the scalding tanks to heat the contained water to about $60^{\circ} \mathrm{C}$ so that intact carcasses after exsanguination can be immersed into the tanks before hairs and bristles can be removed.

Ground water is extracted from a $250 \mathrm{~m}$ depth borehole well to serve all the activities of this slaughter house. Simple sand filter is used to treat the water before use. A settling tank with dimensions $30 \mathrm{~m} \times 40 \mathrm{~m} \times 2.5 \mathrm{~m}$ was constructed to retain the wastewater for some time before discharge.

\section{Phong Phu Slaughter House}

Phong Phu Slaughter House is located in the newly urbanized district of Binh Chanh, about 15 $\mathrm{km}$ west from the city centre, and is within a residential area. This slaughter house is the smallest among the six slaughter houses selected for this study. With a total area of about $500 \mathrm{~m}^{2}$, this site was designed for slaughter capacity of 50 head per night pig kill. However, its actual capacity now is about 100 head per night pig kill.

Maximum number of workers at the site is 20 . The working time every night starts from 0:00 and ends at around 4:00. Wood and rice husk is served as main energy sources to heat four scalding tanks.

Ground water is extracted and passed through a sand filter into two collection tanks, $2 \mathrm{~m}^{3}$ each, before being distributed for use. A small septic tank was constructed to treat wastewater before discharging into a brackish water canal just behind the site. 


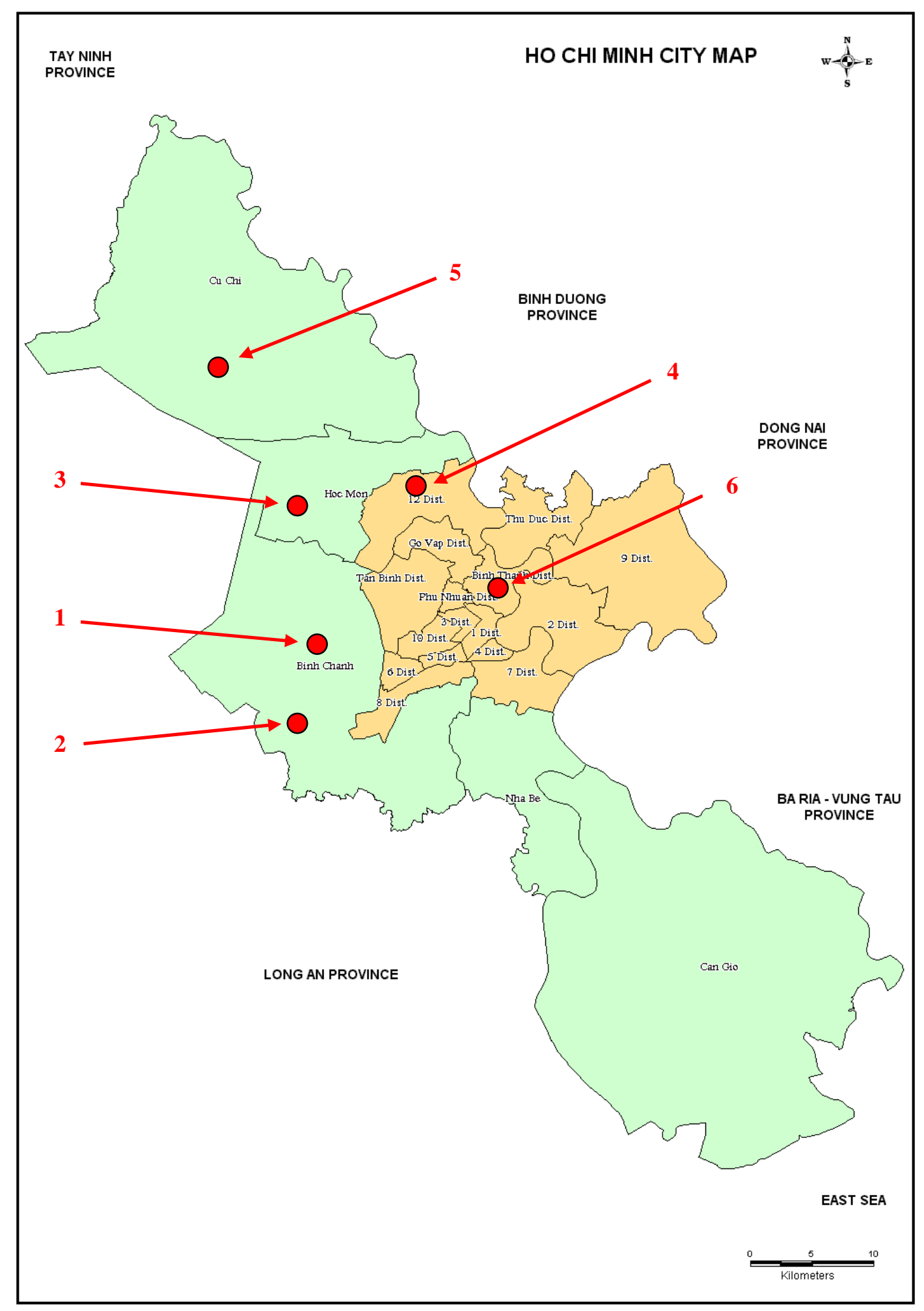

Figure 1. Location of the slaughter houses studied in Hochiminh City 


\section{Ba Diem Slaughter House}

Ba Diem Slaughter House is located in Hoc Mon District which is classified as one of the six outskirt districts of Hochiminh City. It is about $20 \mathrm{~km}$ North West from the city centre and is within a thinly populated area.

The design capacity of the site is reported of 500 head per night pig kill, meaning that the slaughter house was designed to be of medium-sized. However, its actual capacity is only 150160 head per night pig kill, and hence it has been considered for a long time as a small-sized slaughter house. Total area of the site is about $1,500 \mathrm{~m}^{2}$, which seems too confined even for the existing slaughter capacity, since a large space within it is used for pigs to rest.

The site is shared by seven "owners", which use wood to heat their scalding tanks. Ground water is extracted for use. No water treatment measures are practised. Wastewater is discharged untreated.

\section{District 12 Central Slaughter House}

District 12 was recently formed as an urban district from a part of suburban district of Hoc Mon. District 12 Central Slaughter House is located about $15 \mathrm{~km}$ North from the city centre. The location is considered to be as isolated from residential areas.

The slaughter house was constructed and put into operation in 2000 with design capacity of 400 head per night pig kill. Often its working capacity is 300 head per night pig kill. On its $3,000 \mathrm{~m}^{2}$ area piece of land, this slaughter house is shared by four business owners. They have an average number of 60 people working every night. This site is classified as a medium-sized slaughter house.

This slaughter house is the only one where gas (LPG) is used to heat the scalding tanks. Ground water is extracted for use. No water treatment is accompanied, as reported by the owners, thanks to the high quality of the raw water. Wastewater is passed through a settling tank before discharge into a vegetable field and infiltrates thereafter.

\section{Cu Chi Town Slaughter House}

$\mathrm{Cu}$ Chi Town Slaughter House is located in the rural district of $\mathrm{Cu}$ Chi, about $30 \mathrm{~km}$ from city centre. This site belongs to the North West $\mathrm{Cu}$ Chi Industrial Park, and therefore is isolated from residential areas. The entrepreneur of this facility is the $\mathrm{Cu}$ Chi Trading Company, who rented the facility to three slaughter businessmen to share the works.

This facility is the only one among the small- and medium sized slaughter houses in Hochiminh City that has a cattle slaughtering license. It was designed to slaughter 40 cattle and 50 head per night pig kill. The real number of animals slaughtered every night is 40 cattle and 30 pigs. Cattle slaughter starts at 21:00 and finishes at 1:00 AM of the next morning, then pig slaughter follows till 4:00 AM.

Scalding tanks used for pig slaughtering are heated by firing wood. Ground water is extracted on-site for the use without any primary treatment. Wastewater is passed though a tank before discharge out for infiltration into the adjacent ground.

\section{Nam Phong Slaughter House}

Nam Phong Slaughter House is located in Binh Thanh District which is a very central district of Hochiminh City and is only about $2 \mathrm{~km}$ North East from the city centre. The slaughter house is located within a densely populated area. The legal owner of this slaughter house is the Saigon Agriculture General Corporation. 
In terms of slaughter capacity, this slaughter house is currently among the biggest in the whole country. Its design capacity is reported of 800 head per night pig kill, however, its actual capacity is between 1100-1200 head per night pig kill. Since the total number of employees at the site is less than 200, the Nam Phong Slaughter House has been considered for a long time as a medium-sized slaughter house. This traditionally manual slaughtering part of the Nam Phong Slaughter House uses tap water for washing and cleaning the carcasses and ground water for flushing and cleaning the kill floors. The site is shared by 17 slaughter businessmen with their workers' groups. LPG is used by all 17 groups to heat their scalding tanks. Ground water is extracted by pumping from 17 drilled wells for separate use of each group. No water treatment is practised.

Besides the traditionally manual slaughtering as mentioned above, Nam Phong has recently been installed a semi-mechanical processing line for pig slaughtering. Thus, Nam Phong became the only medium-sized slaughter house in Vietnam that has a semi-mechanical processing line. This line was recently installed by the Metro Superstore Group through an agreement with the Nam Phong Slaughter House to make monopoly of high quality pork supply for its superstore system located in Hochiminh City. The capacity of this line is 40-50 head per night pig kill, but can also increase up to 80 head per night pig kill during weekends and on holidays as required by the market demand. This new semi-mechanical processing line uses tap water for all steps of the slaughter process including the flushing and cleaning of the kill floors. Some difference between the two types of slaughtering processes practised at the Nam Phong Slaughter House can be shown in Figures 2 and Figure 3.

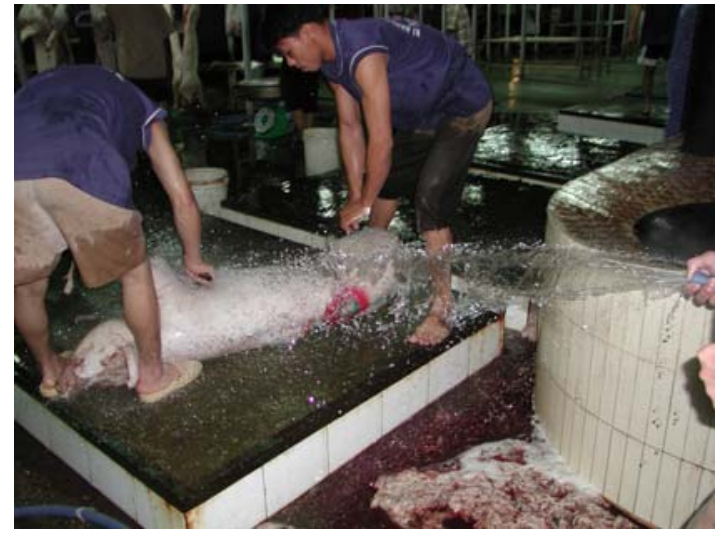

Figure 2 . The traditionally manual slaughtering at Nam Phong Company

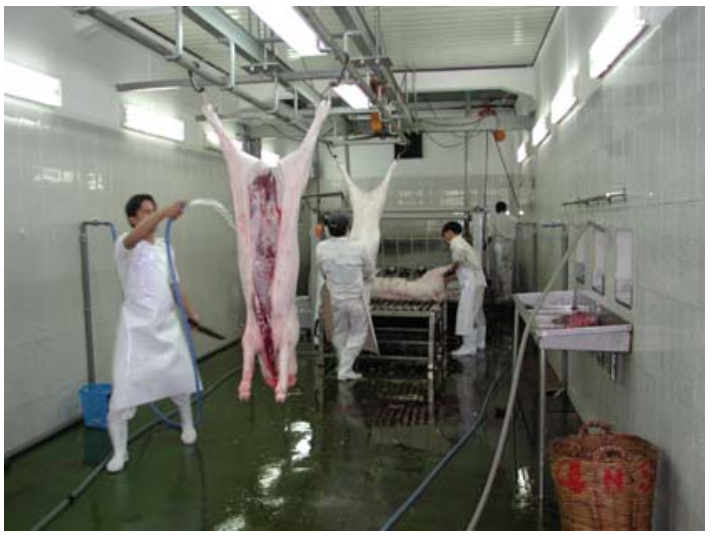

Figure 3. The new semi-mechanical processing line at Nam Phong Company

In terms of area, Nam Phong Slaughter House is also among the biggest ones. Total area of the site is about $7,500 \mathrm{~m}^{2}$, of which about $4,000 \mathrm{~m}^{2}$ is area the slaughter floor while the remaining $3,500 \mathrm{~m}^{2}$ is for office, internal roads, green cover and also a large space for pigs to rest.

Although Nam Phong is the only slaughter house in Hochiminh City that has installed a wastewater treatment, its wastewater is still discharged untreated into a tributary of the Saigon River because the treatment capacity of the wastewater system is as low as only $10 \mathrm{~m}^{3} / \mathrm{h}$.

\subsection{Slaughtering process and its waste stream}


Through direct observation during on-site visits and direct interviews conducted with workers, it has been clear that not depending on the size nor the location, all the studied slaughter houses employ the same working steps and hence their waste streams are also similar, except for the fact that cattle slaughtering is slightly different from pig slaughtering and this difference will also be included in the description below.

The steps of pig slaughtering are almost the same at all six studied slaughter houses and are shown in Figure 4. The steps of cattle slaughtering at the $\mathrm{Cu}$ Chi Town Slaughter House are shown in Figure 5. All the steps, accompanying the generation of wastes at each step, are summarized as follows:

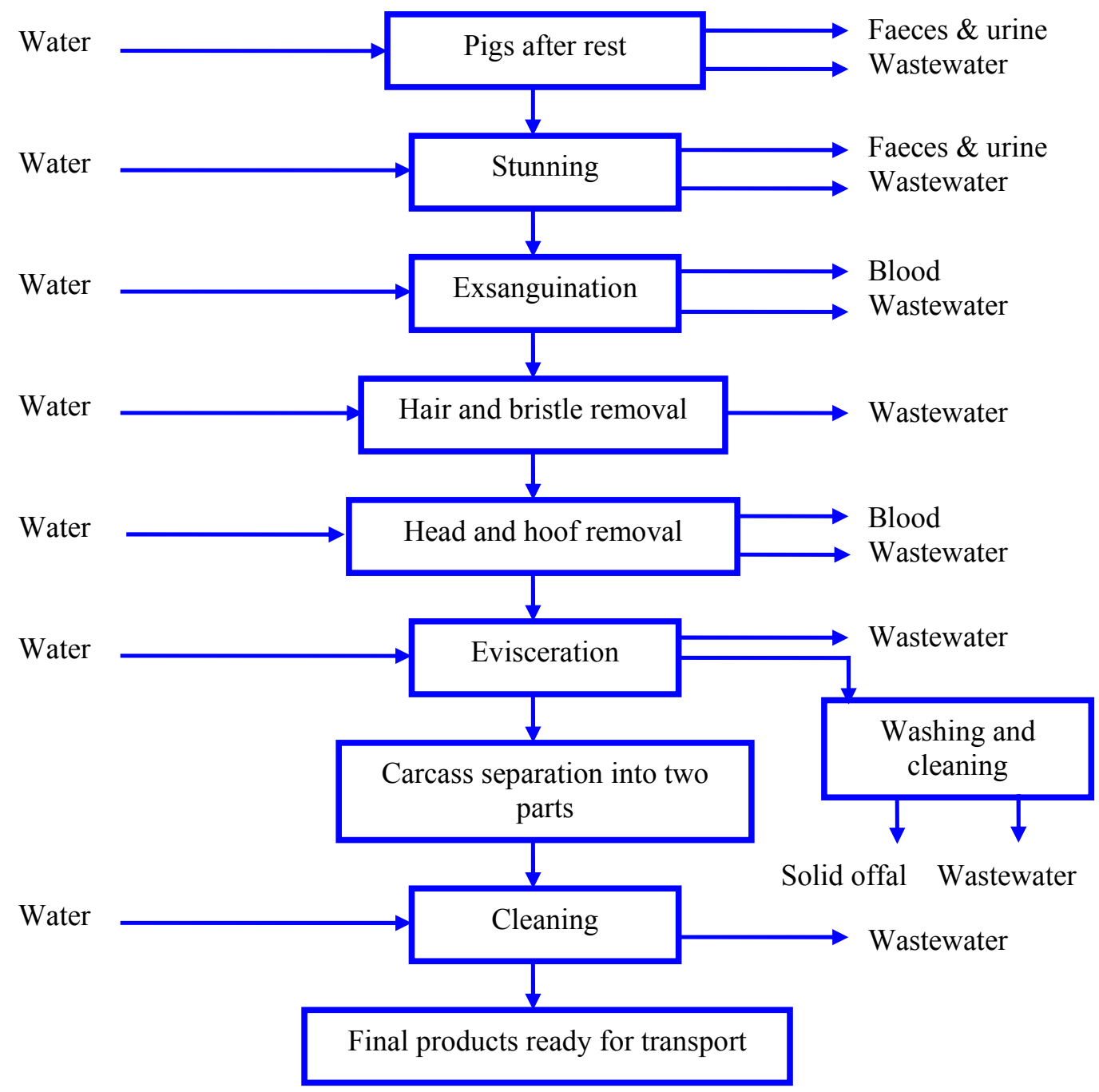

Figure 4. Process scheme and waste stream of pig slaughtering

\section{Preparation for slaughter}

A rest period of at least 12 hours for cattle and 6 hours for pigs is required. During the rest period, animals are not fed but can be provided with water. In case the rest period is more than 24 hours, 
cattle are fed. On the floor there may often be found feces and urine, and sometimes feed residues. Every day water is used to wash the floor. Wastewater is generated from this activity.

\section{Stunning}

Animals must be stunned or rendered unconscious before they are exsanguinated. Pigs at all the studied sites are stunned by passing an electric current through the brain. Cattle at the $\mathrm{Cu} C h i$ Town Slaughter House are stunned by sticking a sharp knife into spinal cord after they are restrained in a narrow pen.

Pigs are usually stunned at a place still within the rest area but just next to the exsanguination area. Cattle at the $\mathrm{Cu}$ Chi Town Slaughter House are stunned on the kill floor because the entire slaughter process is manual. Sometimes feces and urine may be found at stunning area and have to be cleaned later by water, resulting in wastewater generation.

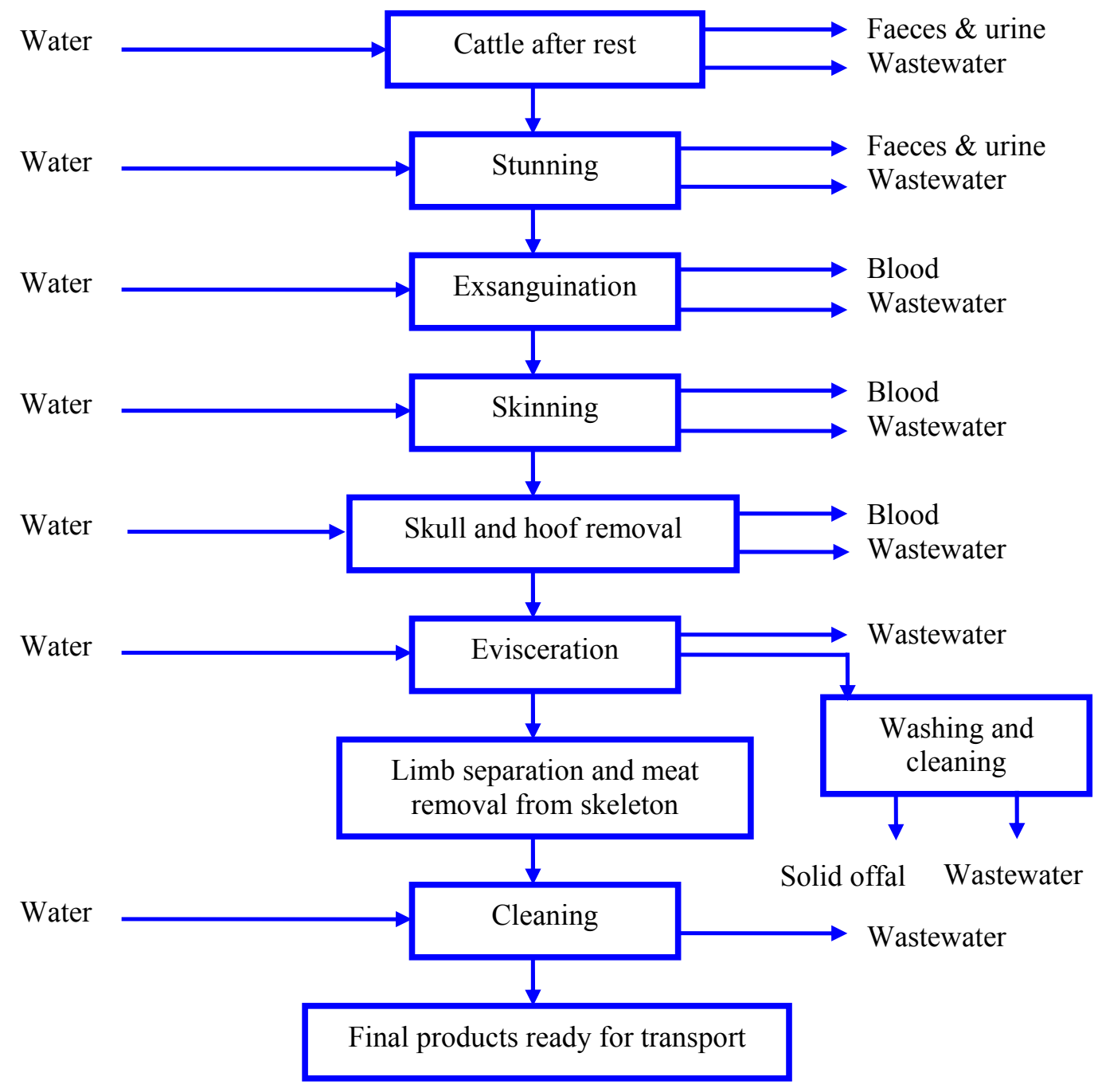

Figure 5. Process scheme and waste stream of cattle slaughtering 


\section{Exsanguination}

After being stunned, cattle and pigs are usually exsanguinated by a puncture wound which opens the major blood vessels at the base of the neck, not far from the heart. Blood is often found on floor during exsanguination. The area is therefore cleaned by water at the end of the working shift.

\section{Hair and bristle removal or skinning}

After exsanguination, pork carcasses are immersed in a scalding tank that contains water at about $60^{\circ} \mathrm{C}$. Scalding at this temperature normally lasts for five minutes. Hair and bristles are then removed from the carcasses by using sharp knives. Blood is found in the scalding water which is disposed off with all types of wastewater generated on-site after the working shift. Blood drops also leak down to the floor during this step, and are later all washed out by water. Usually toenails are also removed at this step. A main part of removed hairs and bristles is then dried at the front of scalding tank ovens, and then is put into the fire and is burnt with wood. The remaining part of removed hairs and bristles is washed out by water when the kill floor is cleaned, and thus is accompanied with wastewater in the drainage.

At cattle slaughtering, after exsanguination beef carcasses are skinned to obtain the hide for tanning. The carcasses are opened by using a sharp knife to make a straight cut and the hide is manually detached in the ventral region of the head and body, and on the medial faces of the limbs. Blood residues and wastewater are generated during the skinning.

\section{Head or skull and hoof removal}

The animal heads are then remover by workers using sharp knives. Then the heads are washed with water and ready for being transported by middlemen to the market.

At cattle slaughtering, the animal heads are also removed at this step after being skinned. The hide remaining on the heads is further remover by using knives. The muscles from the cheeks and scalp are removed from the head. Then the skull is split open and the hypothalamus and pituitary glands are removed and put into special collection baskets and are then ready to be transported to the market. The skull and jaw bones are then sold with other bones to be made into food ingredient sauce (know as magi) or ground up and processed into animal feed.

Blood drops leak to the kill floor at this step and water is used to wash the floor later, resulting in wastewater generation.

\section{Evisceration}

Animal carcasses are then eviscerated by pulling out the bladder, intestines and mesenteries, rumen and other parts of the stomach. After cutting through the diaphragm, plucks (including heart, lungs, liver, pancreas, caul fat, spleen and trachea) are removed. The large and small intestines are separated and passed to a separate area where they are washed and cleaned intensely by water.

The intestine cleaning area is usually located next or very close to the animal rest area and uses a biggest amount of water. At all the visited sites, water was running freely from taps at these areas for the workers to clean the animal intestines.

After being cleaned and separated, some parts for example lungs and caul fat are sent to cookers where they are processed for grease and animal feed. Most of other parts of the plucks are sold at the market as edible products. 


\section{Carcass or limb separation}

At pig slaughtering, workers then separate the left and right sides of the pig carcass by cutting down the midline of the carcass, through the vertebral column. Water is used right after the carcasses have been separated and the two parts are then hung on stainless steel hooks.

At cattle slaughtering process, the carcasses are separated into five main parts including four parts with a limb at each and the remaining part including the whole bone and vertebral system. The limb parts are hung on stainless steel hooks. The meat of the remaining part is then separated from the bone system by sharp knives and later all also hung on stainless steel hooks as final products of the process. Unlike at pig slaughtering, the cattle separated meat parts are not washed with water.

Blood drops down to the floors where the separated meat parts are hung. The floors are then cleaned with water.

\section{Final cleaning}

Final cleaning is applied for pork carcasses when they have been separated and hung on stainless steel hooks. Only now they are considered as final main products of the process and just wait for the middlemen to transport them to the market. Final cleaning using water is not applied for cattle slaughtering.

\section{Environmental problems and impacts}

\subsection{Uncontrolled use of ground water}

Through the field surveys to the studied slaughter houses, it has been observed that one of main environmental problems related to the slaughtering activities is the uncontrolled use of ground water. At all the six studied slaughter houses, ground water is extracted by pumping water out from drilled wells and bore holes which were made at different depth depending on the geological characteristics of the locations.

As it can clearly be seen in Figure 4 and Figure 5, water is used at almost all steps of the animal slaughter processing. No one from the six studied slaughter houses had any means to control the amount of water used. Ground water is therefore pumped freely as needed, and in all the studied cases it was observed that the amount of ground water extracted for use was always exceeded the actual amount needed. A lot of water in fact was wasted.

Because no records were available, nor any water meter was available on-site, exact data on the amount of ground water use could not be conducted at all the studied slaughter houses. This study therefore could only conduct the measurements on water use through an in-depth study at the Nam Phong Slaughter House via measuring the tap water consumed for the processing. Direct interviews with responsible persons at the new semi-mechanical slaughter line of this slaughter house, accompanied by checking some available records, revealed that regardless of the animal weight ${ }^{2}$ an average amount of about 400 liter of tap water is consumed for slaughtering one pig. While tap water is rather costly, this amount of water use would mean almost minimum as it has to be saved and economically used for the business profit. This would also mean that the amount of ground water used for slaughtering a pig should be much higher than 400 liter where ground water used for the processing, because extraction of ground water is free of charge (Tran Thi My Dieu, 2003) except for a little charge for electricity consumed for pumping.

According to Article 24 of the Law on Water Resources (National Parliament of the Socialist Republic of Vietnam, 1998), the extraction of ground water for use in industry, 
agriculture, aquaculture etc. should only be conducted after being permitted by the competent administrative authorities. This article was later made more clearly by Decree 179/1999/ND-CP (Government of Vietnam, 1999) in which Article 9 states that the competent authority of issuing permit for ground water extraction with capacity of from $1,000 \mathrm{~m}^{3} /$ day is the Ministry of Agriculture and Rural Development, while less than $1,000 \mathrm{~m}^{3} /$ day is the city/provincial People's Committee. Besides, Article 8 of this Decree also requires the ground water users pay for permit issue and for water use. Moreover, Article 23 of the Law on Water Resources requires water users to provide data on water use for the purpose of statistics and evaluation whenever requested.

In short, it is now clear that none of the above mentioned legal requirements have been implemented in the case of slaughter industry in Vietnam. Although the Law on Water Resources and other accompanying legal documents have been put in force for about four years, they seem to have never been promulgated to the entrepreneurs of the animal slaughter industry, and thus a huge amount of ground water is being used every day out of the necessary control. The lack of monitoring in this case might result in some unexpected environmental consequences for ground water, in terms of both quantity and quality.

\subsection{Discharge of untreated wastewater}

Since the water used for slaughtering activities does not form a part of the final products, the amount of wastewater discharged from this industry is as much as the amount of water used. A measurement campaign conducted by this study recently shows that around $950 \mathrm{~m}^{3}$ of wastewater was discharged during only five working hours from the Nam Phong Slaughter House when some 1100 pigs were slaughtered.

A recent study (Ministry of Science, Technology and Environment, 2000) shows that slaughterhouses threaten the environment by discharging their untreated wastes, especially wastewater, which contains up to $70-80 \%$ of organics, including cellulose, proteins, amino acids, fats etc. released from the animal feces and blood. In addition, the wastewater can also contain parasite eggs and pathogenic bacteria that might easily contaminate the receiving environment and endanger human health.

Wastewater samples from the studied slaughter houses were collected and analyzed by this study. Table 3 summarizes the analysis results carried out by laboratory of the Vietnam Institute for Tropical Technology and Environmental Protection (VITTEP)

Table 3. Analysis results of some slaughter house wastewater samples Hochiminh City

\begin{tabular}{||l|c|c|c|c|c|c||}
\hline & Site 1 & Site 2 & Site 3 & Site 4 & Site 5 & Site 6 \\
\hline $\mathrm{pH}$ & 5.6 & 5.8 & 6.2 & 5.9 & 6.8 & 6.6 \\
\hline $\mathrm{TSS}(\mathrm{mg} / \mathrm{l})$ & 216 & 82 & 232 & 188 & 134 & 162 \\
\hline $\mathrm{BOD}_{5}(\mathrm{mg} / \mathrm{l})$ & 1550 & 1220 & 1370 & 980 & 1210 & 1520 \\
\hline $\mathrm{COD}(\mathrm{mg} / \mathrm{l})$ & 2830 & 1980 & 1840 & 1710 & 1690 & 2280 \\
\hline$\sum \mathrm{N}(\mathrm{mg} / \mathrm{l})$ & 35.2 & 24.8 & 33.2 & 31.7 & 23.3 & 38.2 \\
\hline$\sum \mathrm{P}(\mathrm{mg} / \mathrm{l})$ & 6.1 & 3.7 & 5.4 & 6.8 & 4.1 & 5.6 \\
\hline$\sum \begin{array}{l}\sum \\
\text { Coliforms }\end{array}$ & $\geq 240000$ & $\geq 240000$ & $\geq 240000$ & $\geq 240000$ & $\geq 240000$ & $\geq 240000$ \\
\hline
\end{tabular}

Sours: VITTEP, March - July 2003.

The very high concentrations of pollutants such as BOD, TSS, N and P in the wastewater are the result of blood, intestines, and solid offal generated from the slaughter processing. Therefore, any reduction of these matters would result in lowering the pollution concentration, as thus leading to the reduction of pollution loads discharged into the environment. 
The discharge of a huge amount of this type wastewater untreated with such high concentrations of pollutants can seriously threaten water quality of the receiving bodies. In fact, the wastewater generated by the studied slaughter houses is discharged whether to tributaries of rivers or to vegetable fields for infiltration. Although national environmental standards were promulgated from 1995, they did not seem to work especially in this case. With the number of 5,200 pigs and 150 beeves/buffaloes slaughtered in Hochiminh City, a simple calculation easily results in a figure of roughly 15 tones of BOD in the wastewater is discharged into the receiving environment. The lack of monitoring (Phung Thuy Phuong, 2002 and Tran Thi My Dieu, 2003) in this case could lead to unforeseen degradation of both surface and ground water.

\subsection{Location}

Although the majority of the existing slaughter houses in Hochiminh City are located in suburban districts, the problem of location occurs more and more seriously. The recent fast rate of urbanization in the city makes more and more slaughter houses to become neighbors of residents.

More and more residents move closer to slaughter houses because the available land becomes less and less, and because the land becomes much more expensive in the last few years. As reported by the Sub-department of Veterinary of Hochiminh City (2002a and 2002b), among the existing slaughter units 19 are located within densely residential areas, the same number are located within thinly populated areas, and only five are really isolated from residential areas. The Ministry of Commerce and Ministry of Agriculture and Rural Development (1997) in their interministerial circular No $05 \mathrm{LB} / \mathrm{TT}$, at Article 2.1 of Part A, require slaughter houses be located at least $100 \mathrm{~m}$ from residential areas. This requirements obviously seem too strict to most of slaughter houses nowadays and will probably have no effects in the coming future.

Another fact related to the location problem is that because of the local custom of consumption, which demands almost only fresh meat, all the medium- and small-sized slaughter houses in Vietnam are in operation from midnight to about 4 o'clock AM so that fresh meat can be ready at the centralized open markets early enough for the middlemen to be able to deliver the meat to the morning markets scattered within the city.

Interestingly is the fact that although most of the small-sized slaughter houses are located amidst residential neighborhoods and operate from midnight till early of the next morning, there have hardly been any complaints from the neibough residents. An important reason for this has been revealed when using the network analysis developed by Mol (1995). Analysis of the societal network of the small-sized slaughter houses in Hochiminh City shows that in all cases their neibough residents are mainly relatives and, what is more important, is that in most cases they all share the slaughter business.

In the case of medium-sized slaughter houses, the situation is not much different from the case of small-sized ones. All the medium-sized but also most of small-sized slaughter houses in Hochiminh City are actually not single slaughter houses, but rather "clusters" of some small "lines" owned by different "business owners". The workers are mainly relatives or neighbors of the owners. In fact, these business owners gather into a place to get the economy-of-scale advantages in terms of rent. Normally, the real entrepreneurs of these facilities are either the real owners of the piece of land, or leaseholders, and are the legally registered entrepreneurs of the enterprises.

\subsection{Obsolete technology}

Obsolete technology is, among others, one of the difficulties and limitations faced by SMEs in general in Vietnam (Frijns, 2003). This is not an exception for small- and medium-sized slaughter 
houses. In order to keep the price competitive, none of the small- and medium- sized slaughter houses in Vietnam, except for the Nam Phong Slaughter House as described above, have installed any mechanical line for the processing. This, however, not only is typical characteristics of the existing slaughter houses in Vietnam, but also can prove some advantages over modern technology, which can further be clarified by taking an analysis of the situation of VISSAN.

VISSAN is the only slaughter house in the country that has modern mechanical lines for slaughtering process and a cooling room for meat product processing. However, because of rather high operating costs, including costs for electricity and for skilled labor, VISSAN has gradually lost its advantages due to price disadvantage on the market competition. Thus, although designed to slaughter 2,400 pigs a day by using three modern mechanical lines, VISSAN now can only slaughter only 400 pigs a day as average. Moreover, in order to cope with the market competition, the slaughtering at VISSAN is now conducted mainly by hand as it is done at all other slaughter houses. The modern lines here are put into operation only for example when serving special contracts for meat export or when a custom requires with a special agreement.

\section{Environmental management}

In Vietnam, the Ministry of Natural Resources and Environment (MONRE), formed in 2002 by merging the former General Department of Land Use, General Department of Hydrometeorology, and the National Environment Agency from the former MOSTE, is the central policy- and decision-making body with overall responsibility for the environment. Environmental tasks of MONRE remain the same as of the former MOSTE, i.e. to develop legislation and regulations, control and enforcement programmes and monitoring systems for environmental protection throughout the country. At the city/provincial level, the local environmental authorities, known as Department of Natural Resources and Environment (DONRE), have an important role in environmental management and the implementation and enforcement of regulations within the territory of the city/province.

Vietnamese environmental policy style is somehow similar to a command-and-control and bureaucratic environmental policy, which has been argued by various authors (e.g. Huber, 1991) for the limited successes, especially in the more advanced phases of environmental reform. The conventional model of command-and-control governs the development of Vietnamese environmental policy, which is characterized by laws, standards and regulations pertaining to emissions and products, and a top-down implementation of legislation. Although Vietnam's Law on Environmental Protection (1994) provides the legal framework for, and sets out the functions and duties of, environmental management institutions at all levels, from the central government to the local authorities, for different reasons, but mainly because of the cultural characteristics, a strict command-and-control approach does not work well in Vietnam (Frijns et al., 2000 and Phung Thuy Phuong, 2002).

Due to the lack of finance and manpower, adequate environmental monitoring, legislation, and control for industries in general and for SMEs in particular is absent, and thus makes enforcement rather difficult. Mol and Frijns (1998: 125) underline that by claiming that "perhaps the most important provisions in the (Vietnamese) Law on Environmental Protection for present-day environmental policy-making are those on EIA [Environmental Impact Assessment]". Mol and Frijns (1998), Phung Thuy Phuong (2002) and several contributions in Mol and van Buuren (2003) point out that although a set of Vietnamese environmental standards covering most fields of environmental pollution has been formulated (TCVN-1995 and TCVN 2001), the lack of human resources, knowledge and experience of administrative implementation and enforcement within the governmental agencies seriously limit the use of these standards in practices. For many reasons, this especially relates to the small and medium sized production units. 
Regarding slaughter industry, in 1995, the Government of Vietnam by its Decree 02-CP dated 05 January 1995 classified slaughtering into a group of services which can only be licensed with mandatory conditions (Government of Vietnam, 1995). Condition 9.2a in this Decree requires slaughter houses "should be located properly as planned by the competent authorities". In addition condition $9.3 \mathrm{~b}$, also applicable for slaughter houses, required "the participants of this business have to ensure health standards". The conditions for slaughter then were redefined by Government Decree 11-CP dated 03 March 1999 (Government of Vietnam, 1995) to consist of four conditions including (a) to be registered legally, (b) to have infrastructure as standardized by the state competent authorities, (d) to ensure the workers' health, and (e) to meet the requirements on environmental protection and fire prevention. The last general statement, similar to many other legal documents related to environmental issues, has never been treated as it exists in the daily life, simply because of the lack of adequate legislation and enforcement.

\section{Pollution prevention: a right approach?}

In order to struggle against environmental degradation caused by industrial pollution, the environmental authorities of Hochiminh City have been working hard with the hope to find a proper solution. During the last decade, the following measures have been being implemented in Hochiminh City:

Group A: pure command-and-control based pollution control measures, including:

- To punish the industries violating environmental regulations and standards, mainly in the form of fiscal fines;

- To oblige the polluting industries implement (end-of-pipe) treatment facilities;

- To relocate the heavily polluting industries to industrial parks; and

- To close down the most polluting industries that can neither improve their environmental performance, nor be able to relocate.

Group B: socio-economic measures, including:

- To introduce cleaner production to industries and encourage them to implement waste auditing and cleaner production measures

It should be emphasized that the measures of group A mentioned above were started a decade ago. There is no doubt that some successes were gained by implementing these measures. First, it has been reported that because of being fined for violating environmental standards, hundreds of industrial enterprises have installed pollution control facilities. This, from one side looks like as the installed pollution facilities contribute significantly to the reduction of industrial pollution in the city, but from the other side this really costs the implementing enterprises a lot. Further more, as described above, due to the lack of adequate monitoring, most of the installed pollution control facilities have normally not been put into operation for economic reason. The facilities are only put into operation sometimes a year for maintenance run or for showing the environmental inspectors that they do operate working.

Second, due to failing to implement any pollution control measures hundreds of heavily polluting industrial enterprises were closed down. This can from one hand contribute to the reduction (though very minor) of industrial pollution in the city, but from the other hand this has also created the loss of jobs of thousands of workers.

Nevertheless, the effectiveness of the two above mentioned measures have never been evaluated properly. Thus, debates on this issue are going on between the management authorities 
from one side and industrial entrepreneurs and scientists from the other side. For some reasons, the city authorities now focus on the relocation program which aims at relocating the polluting industries (of all sizes) into industrial parks. Regarding this issues, Frijns (2003) has studied carefully in details the advantages and disadvantages of relocation of SMEs to industrial zones outside HCMC. In the recent study (Frijns, 2003) the author also analyzed an alternative to relocation, which is the renovation of the SMEs at their current location, by introducing costeffective cleaner production measures.

Pollution prevention or cleaner production aims at internal production processes that are more energy efficient, use fewer resources, and re-use waste materials and thus not only reduce environmental impacts but may also reduce economic costs (Frijns, 2003). In the case of smalland medium-sized slaughter houses in Hochiminh City, this approach sounds like just what is needed. The easiest way to control the current uncontrolled use of ground water at the slaughter house can only be done by improving the existing housekeeping, which is the first and cheapest step of pollution prevention measures. By successfully controlling the use of (ground) water, the slaughter houses will be able not only to use fewer natural resources but also reduce the amount of waste waster discharged into the environment.

Further more, applying the pollution prevention approach by just some minor adjustments, the slaughter houses could tremendously reduce the pollution loads discharged into the environment. This has been verified by the case study at VISSAN recently (SIDA, DOSTE of Hochiminh City and UNIDO, 1999), where it was reported that thanks to the cleaner production measures applied, VISSAN now saves the water use of $250 \mathrm{~m}^{3} /$ day, reduces the amount of wastwater at $20 \%$ which is equal to $90,000 \mathrm{~m}^{3} /$ year, and reduces the BOD and COD loads of 310 ton/year. It should, however, be noticed that nothing is cost free. Therefore certain consideration and balance have to be made by the enterprise before it decides to take some cleaner production measures. Frijns (2003) has mentioned that the cleaner production measures that require substantial investments would meet with severe difficulties, especially in the small-scale industry sector where the financial capacity is really limited and where the struggling for a living is much more important than anything else.

Although it is now clear that pollution prevention or cleaner production has so many advantages for SMEs in general and for small- and medium-sized slaughter houses in particular, one of the limitations is that most of the cleaner production programs in Vietnam Cleaner are still dedicated to the larger industries, as are the other governmental and international programs (cf. Tran Van Nhan and Leuenberger, 2003). The case study of VISSAN mentioned above is a clear example of this. VISSAN was the only slaughter house in Vietnam that was selected for the UNIDO demonstration project on cleaner production (SIDA, DOSTE of Hochiminh City and UNIDO, 1999). This causes considerable chalenges in disseminating exemplary experiences about environmental improvements among SMEs in general and slaughter houses in particular.

\section{Conclusions}

This study has found out some environmental issues and problems related to the activities of small- and medium-sized slaughter houses in Vietnam in general and Hochiminh in particular. The study has analyzed and pointed out that main environmental problems caused by the smalland medium-sized slaughterhouses are the uncontrolled use of ground water and discharged of untreated wastewater. Having analyzed the advantages and disadvantages of the currently possible approaches for improving environmental performance of the slaughterhouses, the study came to a final conclusion that pollution prevention would be the best promising approach for solving the environmental problems caused by the slaughter houses in Hochiminh City. In general, this study shares the main conclusion made by the study of Frijns (2003) that states that "in order to successfully control pollution from SMEs, Vietnamese authorities need to find a 
careful balance between cleaner production support activities and enforcement of environmental regulations, including relocation of those small and medium-sized enterprises that continue to be an environmental burden to the residents of Hochiminh City". However, in the specific case of small- and medium sized-slaughter houses in Hochiminh City, this study argues the advantage of pollution prevention approach over relocation to industrial parks.

\section{Acknowledgements}

The author would like to thank Dr. Huynh Huu Loi, Director, Mr. Le Truong Hai, vice chief inspector, and Mr. Huynh Tan Phat, all from the Sub-department of Veterinary of Hochiminh, for their kind assistance provided to me. This study would have never been completed without their facilitation.

\section{Reference}

Department of Veterinary of Vietnam (2003). Report on the inspection of animal slaughter, veterinary hygiene and animal meat trade in Vietnam. Hanoi: The Ministry of Agriculture and Rural Development.

Department of Veterinary of Vietnam, South Regional Office (2003). Report on the inspection of animal slaughter, veterinary hygiene and animal meat trade in South Vietnam. Hochiminh City: The Veterinary South Regional Office.

Frijns, J. (2003). Relocation or Renovation: Greening Small and Medium-Sized Enterprises. In: A.P.J. Mol and J.C.L. van Buuren (eds.), Greening Industrialization in Asian Transitional Economies: China and Vietnam, Lanham: Lexington Books.

General Statistics Office (2002). Statistical Yearbook 2001. Hanoi: Statistical Publishing House.

Government of Vietnam (1995). Decree 02-CP of the Government 05 January 1995 on regulating goods and services with ban, limit and conditions within the domestic market. Hanoi: the Government of Vietnam.

Government of Vietnam (1998). Document No 681-CP/KTN of the Government on guiding strategies and policies for the development of small- and medium-sized enterprises.

Government of Vietnam (1999). Decree 11-CP of the Government on 03 March 1999 on banned, limited, or conditioned services and goods. Hanoi: the Government of Vietnam.

Government of Vietnam (1999). Decree 179/1999/ND-CP of the Government on 30 December 1999 on the implementation of Law on Water Resources. Hanoi: the Government of Vietnam.

Huber, J. (1991). Ecological Modernization: Away from Scarcity, Soberness and bureaucracy. Translation from: J. Huber, "Ecologische modernisering: weg van schaarste, soberheid en bureaucratie". In: A.P.J. Mol, G.Spaargaren en A. Klapwijk (eds.), Technologie en Milieubeheer. Tussen sanering en ecologische modernisering. Den Haag: SDU. Pp. 167 183.

Ministry of Commerce and Ministry of Agriculture and Rural Development (1997). Interministerial circular No $05 \mathrm{LB} / \mathrm{TT}$ of 24th May 1997 guiding the conditions for slaughtering, transportation and trade of pig and cattle meat. Hanoi: Ministry of Commerce and Ministry of Agriculture and Rural Development.

Ministry of Science, Technology and Environment (2000). Technical report: "Impact Assessment of Some Types of Small and Medium Sized Manufacturing Enterprises in the South Vietnam on the Population's Health and the Environment". Scientific report of the program on proper use of natural resources and environmental protection (KHCN-07): "Study on Appropriate 
Technologies for the Treatment of Wastes Generated from Small and Medium Sized Manufacturing Enterprises". Volume 2. Vietnam: Hochiminh City.

Mol, A.P.J. (1995). The Refinement of Production, Ecological Modernization Theory and the Chemical Industry. Utrecht: International Books/Van Arkel.

Mol, A.P.J. and J. Frijns (1998). "Environmental Reforms in Industrial Vietnam", Asia-Pacific Development Journal 5 (2): 117-138.

Mol, A.P.J. and J.C.L. van Buuren (eds.) (2003). Greening Industrialization in Asian Transitional Economies: China and Vietnam, Lanham: Lexington Books

National Parliament of the Socialist Republic of Vietnam (1998). Law on Water Resources. Hanoi: National Parliament of the Socialist Republic of Vietnam.

Phung Thuy Phuong (2002). Ecological Modernisation of Industrial Estates in Vietnam. PhD dissertation, Wageningen University, the Netherlands.

SIDA, DOSTE of Hochiminh City and UNIDO (1999). Project on Industrial Pollution Reduction in Hochiminh City, Case Study on Cleaner Production of Food Processing Sector. Hochiminh City: The Department of Science, Technology and Environment.

Sub-department of Veterinary of Hochiminh City (2003). Report on the activities of staff of Veterinary Sub-department of Hochiminh City during the period 1996-2002. The Class 1 Labour Decoration Awarding Conference. Hochiminh City: The Department of Agriculture and Rural Development.

Sub-department of Veterinary of Hochiminh City (2002a). Report on the inspection of animal slaughter and veterinary hygiene in Hochiminh City. Hochiminh City: The Department of Agriculture and Rural Development.

Sub-department of Veterinary of Hochiminh City (2002b). Report on the inspection of animal slaughter and animal meat trade in Hochiminh City. Hochiminh City: The Department of Agriculture and Rural Development.

Sub-department of Veterinary of Hochiminh City (1998). Report on the inspection of animals, animal slaughter, veterinary hygiene and animal meat products in Hochiminh City. Proceedings of the 6th Regional Veterinary Conference. Hochiminh City: The Department of Agriculture and Rural Development.

Tran Thi My Dieu (2003). Greening agro-industries in Vietnam. Putting industrial Ecology to work. PhD dissertation, Wageningen University, the Netherlands.

Tran Van Nhan and Heinz Leuenberger (2003). Cleaner Production and Industrial Pollution Control in Vietnam. In: A.P.J. Mol and J.C.L. van Buuren (eds.), Greening Industrialization in Asian Transitional Economies: China and Vietnam, Lanham: Lexington Books.

Wolff, P. (1999). Vietnam - The Incomplete Transformation. London: Frank Cass Publishers.

\section{Notes}

1. There is no clear definition to distinguish a slaughter house from a slaughter point. The classification depends very much on the existing local conditions of each province. However it is very common that in big cities and urban areas, a capacity of less than 10 head per night pig kill would be considered as of "slaughter points", whereas in small provinces and remote areas such figure is normally accepted 5 and sometimes even less.

2. In fact pigs for slaughter usually have weight ranging between 100 and $120 \mathrm{~kg}$, this means that the difference in weight from one to another pig is not much. 